\title{
The Effect of Chemical Substance and Immersion Time to Tensile Strength of Bamboo Betung (Dendrocalamus asper) as Chemical Preservation Treatment
}

\author{
Afif Rizqi Fattah ${ }^{1}$, Ken Ninez Nurpramesti Prinindya ${ }^{1}$, and Hosta Ardhyananta ${ }^{1}$
}

\begin{abstract}
Bamboo is one of the materials which availability is overflow and easy to renewable. However, in use of bamboo, it often degraded by biotic and abiotic factors. Preservation is required to keep service life from bamboo that more durable. This research aims to analyze tensile strength of bamboo after have chemical preservation treatment and weather. Bamboo which researched is bamboo Betung (Dendrocalamus asper). This research use a method as this. First, bamboo be cut into tensile test sample, then makes a preserve liquid borax 0,05 $M$ in 1 liters of water, boric acid 0,05 $M$ in 1 liters of water, and mixture borax liquid with boric acid, with volume increase of boric acid liquid in every borax liquid amount as 20,40 and $60 \%$. Then, bamboo immerse in preserve liquid. After that, do tensile test to bamboo sample without weathering, and bamboo sample with weathering. From the result of this research, chemical substance of preserve raise a tensile strength. More time of immersion, tensile strength is drop. Tensile strength of bamboo Betung has not decreased on three days of weathering.
\end{abstract}

Keywords—borax, boric acid, preservation, weathering, tensile strength.

\section{INTRODUCTION}

B amboo can be considered as composite, bamboo filler as reinforcement, and lignin as matrix [1]. Bamboo have a high rigidity with low density. This things probably make a bamboo use as strong material but lighty [2].

Previous research showed that the use of bamboo as an alternative material has the same problem with the wood. Bamboo is not durable, it means the use of bamboo is often degraded by biotic factors such as fungi and insects, and abiotic factors such as cracking, weather, fire, and moisture. This causes make the lifetime of bamboo is short.

Research on preservation using chemicals has long been done by the researchers. However, the use of toxic chemicals and heavy metals as preservatives cause bad effects to humans and the environment. Unlike the preservative boron compounds, namely borax and boric acid. Boron preservative compounds made of bamboo being resistant to fungal and insect attack, in addition to the preservative boron compounds have no adverse impact on humans and the environment if appropriate dosage use. The properties of boron which is odorless, colorless, no reactivity to metal, non-volatile and the prices relatively cheaper than heavy metal-based preservatives, are some of the excess boron preservative compounds. However, bamboo has been preserved with preservative borax or boric acid should not be placed on the ground or damp environment, this is due to preservatives easily leached boron compounds that are likely to exit from the cell wall of bamboo.

\footnotetext{
${ }^{1}$ Afif Rizqi Fattah, Ken Ninez Nurpramesti Prinindya, and Hosta Ardhyananta are with Departement of Materials and Metallurgical Engineering, Faculty of Industrial Technology, Institut Teknologi Sepuluh Nopember, Surabaya, 60111, Indonesia. E-mail: afifrizqif@gmail.com; prinindya@gmail.com; hostaa@mateng.its.ac.id.
}

\section{EXPERIMENT}

Borax and boric acid which used as a preservative, and distilled water as a solvent derived from PT Sumber Utama Kimia Murni. Table 1 is a property of borax, Table 2 is the property of boric acid.

Specimens used in this study is bamboo betung aged 3-5 years. In this study, absorption and retention obtained by calculation according to the ASTM D 141399 standard [3]. Tests performed in this study, namely tensile testing. Dimensions of tensile test samples according to the ASTM D 143-94 standard [4]. Figure 1 is the dimension of the tensile test sample. Preservative solution used was $0.05 \mathrm{M}$ borax in 1 liter of distilled water and $0.05 \mathrm{M}$ boric acid in 1 liter of distilled water. Weight (grams) of borax and boric acid powder, obtained from the following calculation.

$$
\begin{aligned}
& \mathrm{M}=\frac{\mathrm{n}}{\mathrm{vol}} \\
& 0,05 \mathrm{M}=\frac{\mathrm{n}}{1 \mathrm{~L}} \\
& \mathrm{n}=0,05
\end{aligned}
$$

$$
\begin{array}{ll}
\begin{array}{l}
\text { Borax, } \\
\mathrm{n}=\frac{\mathrm{gr}}{\mathrm{Mr}}
\end{array} & \begin{array}{l}
\text { Boric Acid, } \\
\mathrm{n}=\frac{\mathrm{gr}}{\mathrm{Mr}}
\end{array} \\
0,05=\frac{\mathrm{gr}}{381,37} & 0,05=\frac{\mathrm{gr}}{61,83} \\
\mathrm{gr}=19,06 & \mathrm{gr}=3,09
\end{array}
$$

\section{RESULT AND ANALYSIS}

\section{A. Absorption}

Absorption is the amount of fluid preservative contained by the wood after preserved [5]. To obtain the value of absorption $(\mathrm{G})$, sample weight after preservation (T2) reduced sample weight before preserved (T1).

$$
\mathrm{G}=\mathrm{T} 2-\mathrm{T} 1 \text { (gram) }
$$


Table 3 is a chemical preservative absorption in bamboo betung are not being subjected to the weather, B0TPW and B0TP samples not included in the table caption absorption, because the B0TP and B0TPW samples not preserved. Table 4 is absorption of chemical preservatives on bamboo betung after weathering. In Table 4, the most absorption of the samples contained at B72BW samples. Preservatives used in the sample B72BW is borax solution. At B72BW samples, immersion performed for 72 hours. On weathering, beside chemical substance factor which absorbed, the value of absorption is influenced by moisture absorption during weathering. Humidity causes weight of treatment samples more than weight of sample before weathering, this is due to the addition of the water content in the sample when the weathering.

In Table 3, most of the absorption present in the sample $\mathrm{B} 72 \mathrm{~B} / 40 \% \mathrm{AB}$. Preservatives are used in the sample $\mathrm{B} 72 \mathrm{~B} / 40 \% \mathrm{AB}$ is a mixture of borax and $40 \%$ solution of boric acid. In the sample $\mathrm{B} 72 \mathrm{~B} / 40 \% \mathrm{AB}$, immersion performed for 72 hours. Boron does not fixation [6], for allowing continuous boron will diffuse towards the wood. This is the basis, the longer soaking time, preservatives absorption will be even greater.

\section{B. Retention}

Preservative retention is pure weight of preservatives that can be contained by bamboo is preserved. Preservative retention is expressed in units gram $/ \mathrm{cm} 3$ or $\mathrm{kg} / \mathrm{m} 3$ [5]. According to the standard ASTM D 1413-99, retention is,

\section{GC/V x 10}

Where,

$\mathrm{G}=$ (T2-T1) the difference in weight of the sample after preserved and before preserved, or preservatives in pure absorption by the sample

$\mathrm{C}=$ preservative concentration in\%. $\mathrm{C}$ borax preservative is,

$$
\begin{gathered}
\frac{M=10 \% \times \rho}{M r} \\
\frac{0,05=10 \% \times 1,71}{381,37} \\
\begin{array}{c}
19,0685=17,1 \% \\
\%=1,1 \%
\end{array} \\
C \text { boric acid preservative is, } \\
\frac{M=10 \% \times \rho}{M r} \\
\frac{0,05=10 \% \times 1,435}{61,83} \\
\begin{array}{c}
3,0915=14,35 \% \\
\%=0,21 \%
\end{array} \\
V=\text { volume of sample }(\mathrm{cm} 3)
\end{gathered}
$$

Table 5 is a chemical preservative retention on bamboo betung,. In Table 5, the most retention of preservatives on bamboo found in the B72B samples were preserved with borax, and $\mathrm{B} 72 \mathrm{~B} / 40 \% \mathrm{AB}$ samples were preserved with borax $+40 \%$ boric acid. It is influenced by absorption $(\mathrm{G})$ and concentration (C) of the sample $\mathrm{B} 72 \mathrm{~B}$ and $\mathrm{B} 72 \mathrm{~B} / 40 \% \mathrm{AB}$ is larger than other samples.

Table 6 is a chemical preservative retention on bamboo after weathering. In Table 6 , the most retention of the chemical preservatives on bamboo found in the B72BW samples were preserved with borax for 72 hours. If seen from the retention of the sample $\mathrm{B} 72 \mathrm{~B}, \mathrm{~B} 72 \mathrm{~B} / 40 \% \mathrm{AB}$ and $\mathrm{B} 72 \mathrm{BW}$, retention value is still small, it is because the dimensions of the sample in this study is not as big and heavy as wood preservation samples in general. Dimensions of the sample, absorption (G), is directly proportional to the retention obtained. The greater value of absorption $(\mathrm{G})$, retention will be greater

\section{The Effect of Chemical Preservatives to Tensile Strength of Bamboo Betung}

Tensile test using Gotech UTM GT-7001-LC50 series in Laboratory of Metallurgy, Materials and Metallurgical Engineering Department of FTI-ITS. Aims to determine the tensile strength of bamboo as well as determine the effect of chemicals, immersion time and weathering on the tensile strength of bamboo betung.

Table 7 is the effect of chemical preservatives and immersion time on the tensile strength of bamboo betung. Because of different preservatives used, and a sample of bamboo with bark, the grouping of the data used to facilitate analysis.

Table 8 is the effect of chemical preservatives on bamboo betung to tensile strength, and Figure 2 is a graph of the effect of chemical preservatives to tensile strength of bamboo betung. In Table 8 and Figure 2, the tensile strength of B72B sample is higher than the B0TP sample. B72AB sample has a higher tensile strength than sample BOTP and B72B. The increase in tensile strength occurs in the addition (\%) boric acid, as shown by the sample $\mathrm{B} 72 \mathrm{~B} / 20 \% \mathrm{AB}, \quad \mathrm{B} 72 \mathrm{~B} / 40 \% \mathrm{AB}$ and $\mathrm{B} 72 \mathrm{~B} / 60 \% \mathrm{AB}$. The highest tensile strength is B72B/60\%AB sample with 149.37 Mpa.

Figure 3 is the tensile curve of tension - strain which is influenced by chemical preservatives in chemical preservation process of bamboo betung. If seen from Figure 3 , the highest tension owned by $\mathrm{B} 72 \mathrm{~B} / 60 \% \mathrm{AB}$ sample. The average of strain occurs between $3-4 \%$, but the highest strain is owned by B72AB sample. Table 9 is the bark effect to tensile strength of bamboo betung on chemical preservation process, Figure 4 is a graph of the bark effect to tensile strength of bamboo betung on chemical preservation process. In Table 9 and Figure 4, the tensile strength of the BK72B sample is higher than the B0TP and B72B sample. This is because the effect of bamboo bark. Mechanical strength of bamboo is influenced by bamboo bark which containing silica, silica content of bamboo bark affect tensile strength when tensile tested of bamboo betung is fiber direction (axial) [1]. Figure 5 is the tensile curve of tension strain of bamboo betung which is influenced by bamboo bark on chemical preservation process. On figure 5, BK72B sample have a higher tension and strain than $\mathrm{BOTP}$ and $\mathrm{B} 72 \mathrm{~B}$ sample. The strain of BK72B sample between $4-5 \%$, the strain of BOTP and B72B sample between $3-4 \%$.

\section{The Effect of Immersion Time to Tensile Strength of Bamboo Betung}

In the first 24 hours of immersion, preservative absorption takes place most intensively, could even reach $50 \%$ of the total absorption. After that, the absorption rate will continue to decline until the end of the immersion period [5].

Because of the effect of immersion time, the data used is a variation of the immersion time in the chemical preservation process. Table 10 is the effect of immersion time to tensile strength of bamboo betung, and Figure 5 
is a graph of the effect of immersion time to tensile strength of bamboo betung.

In Table 10 and Figure 5, the shortest immersion time is 24 hours on B24B sample, its strength is higher than BOTP and B72B sample. From these data, the longer immersion time, tensile strength is dropped. Tensile strength of bamboo will decrease with increasing water content [7].

The longer period of time needed to immerse the wood, will make the preservation process more effective. It means, the wood will be protected from wood destroying insects. Otherwise, the longer period of time needed to immerse the wood, will make the lower strength of wood than the strength of wood before immersion. This is because the cells making up the wood will be more tenuous and finally unraveled when the wood is immerse in the longer term. The relationship between wood cells would thus reduce the strength of wood [5]. This is also true for bamboo, as the main constituent components of wood and bamboo is almost the same, namely cellulose, hemicellulose and lignin. The difference, in the wood, fibers is irregular. While the bamboo fiber direction (continuous) and wrapped by lignin matrix.

Figure 7 is the tensile curve of tension - strain of bamboo betung which is influenced by immersion time on chemical preservation process. On figure 7, the highest tension and strain obtained by B24B sample. The strain of B24B sample between 4-5\%, the strain of B0TP and B72B sample between 3-4\%.

\section{E. The Effect of Weathering to Physical Properties and Tensile Strength of Bamboo Betung}

Bamboo gets damaged due to weather, caused by differences in atmospheric conditions at the time of weathering of bamboo, such as the rise and fall of temperature and humidity (relative humidity). Conditions were dry and wet bamboo repeatedly, causing damage to the surface of the bamboo. It also explains the relationship between moisture content in wood and bamboo. The more water content, the tensile strength will decrease. Radiation from the sun causes a decrease in cellulose content.

In this study, samples of bamboo is weathering for 3 days. If seen from Table 11 and Figure 8, the tensile strength of bamboo with weathering is higher than the tensile strength of bamboo without weathering. Only on the sample using boric acid preservative, the tensile strength of bamboo without weathering is higher than the tensile strength of bamboo with weathering. In the weathering of wood or bamboo, sun and water are two important factors related to reduction in the quality of wood or bamboo [8].

\section{CONCLUSION}

Conclusions of this study are chemical preservatives increase the tensile strength of bamboo betung. Optimum increasing of tensile strength acquired at borax and $60 \%$ boric acid preservative. Immersion time increase the tensile strength of bamboo betung. Optimum increasing of tensile strength acquired at 24 hours of immersion time. Tensile strength of bamboo betung has not optimum decreased during the 3 days of weathering.

\section{REFERENCES}

[1]. Shigeyasu Amada, Yoshinobu Ichikawa, Tamotsu Munekata and Yukito, "Fiber Texture and Mechanical Graded Structure of Bamboo," Journal of Composites Part B 28, pp. 13-20, 1996.

[2]. Khosrow Ghavami, "Bamboo as Reinforcement in Structural Concrete Elements," Cement \& Concrete Composites 27, p. 637649, 2005.

[3]. ASTM D 1413-99, Standard Test Method for Wood Preservatives by Laboratory Soil-Block Cultures., 2004.

[4]. ASTM D 143-99, Standard Test Methods for Small Clear Specimens of Timber, 2000.

[5]. Suranto Y., Pengawetan Kayu. Bahan dan Metode, 2002.

[6]. Nicholas D.D., Deteriorasi Kayu dan Pencegahannya dengan perlakuan-perlakuan Pengawetan, H. Yoedibroto, Ed., Yogyakarta: Airlangga University Press, 1984.

[7]. Janssen and J. J. A, "The Mechanical Properties of Bamboo Used In Construction," in Proceeding of Workshop Held In Singapore, Singapore, 1980.

[8]. Musrizal Muin, Astuti Arif and Syahidah, Deteriorasi dan Perbaikan Sifat Kayu, Fakultas Kehutanan, Universitas Hasanudin, 2010.

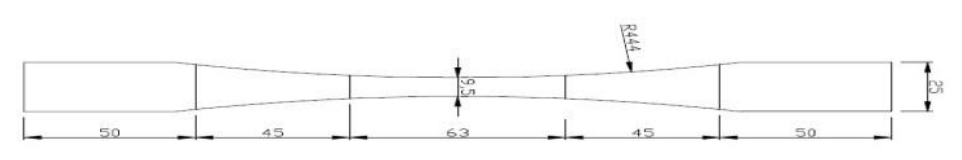

Dimension in millimeter

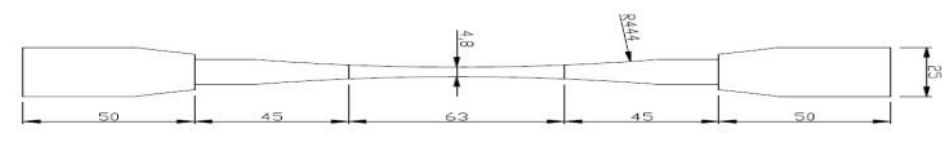

Figure 1. Dimensions of tensile test samples 


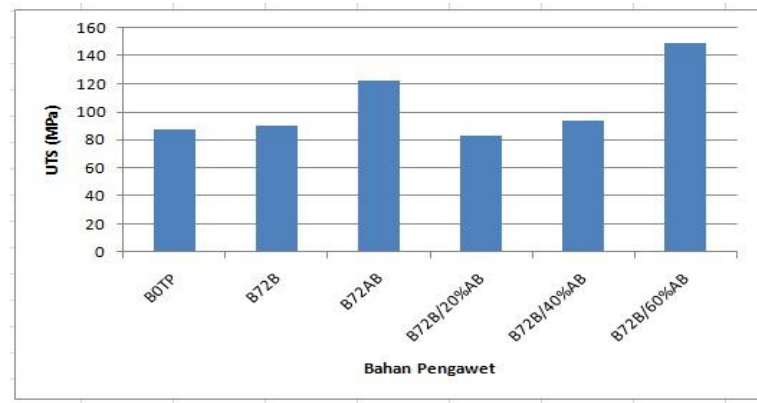

Figure 2. Graph of the effect of chemical preservatives to tensile strength of bamboo betung

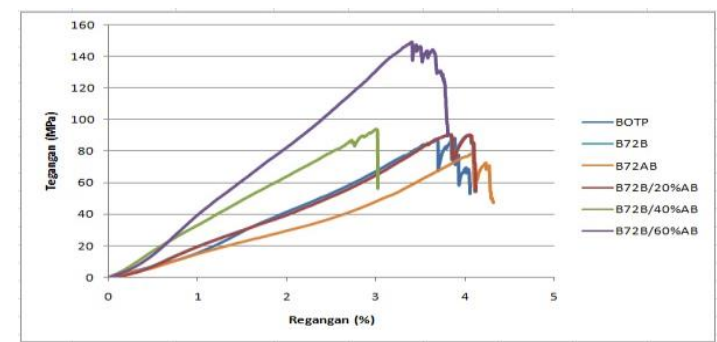

Figure 3 . The tensile curve of tension - strain which is influenced by chemical preservation process of bamboo betung

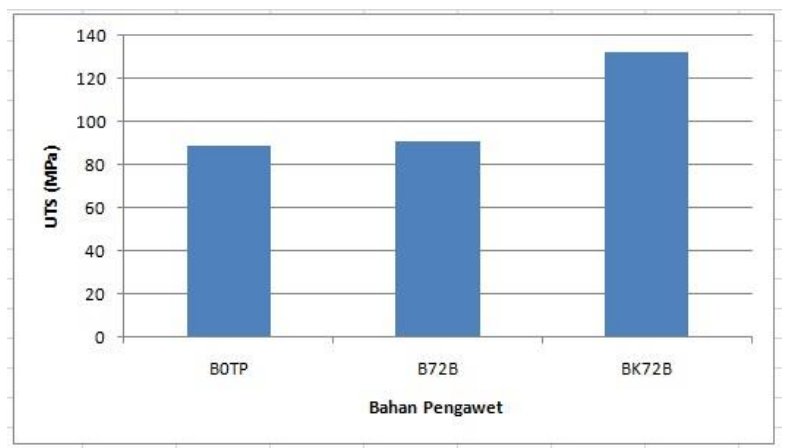

Figure 4. Graph of the bark effect to tensile strength of bamboo betung on chemical preservation process

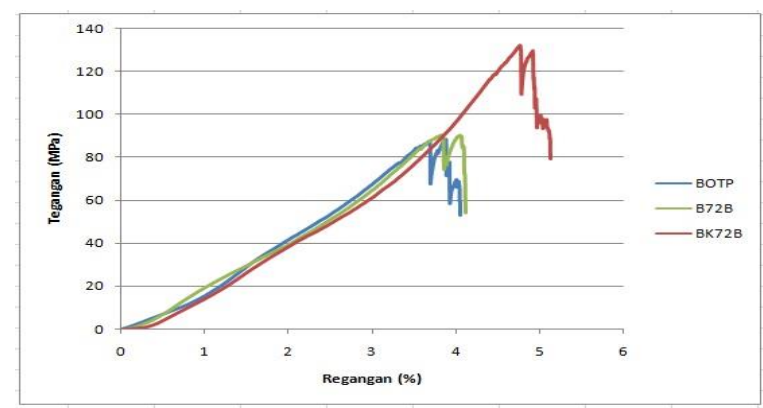

Figure 5. The tensile curve of tension - strain of bamboo betung which is influenced by bamboo bark on chemical preservaton process

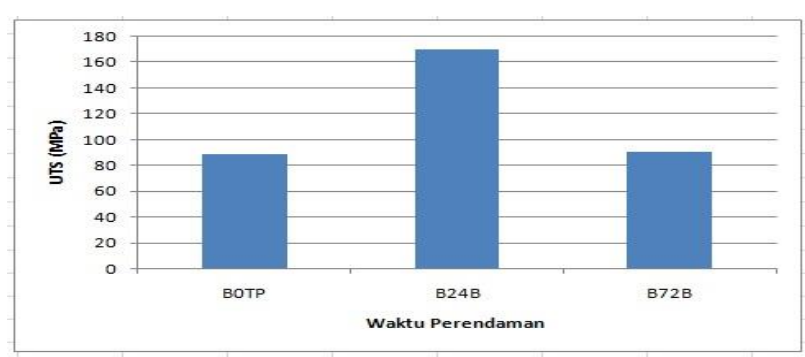

Figure 6. Graph of the effect of immersion time to tensile strength of bamboo betung

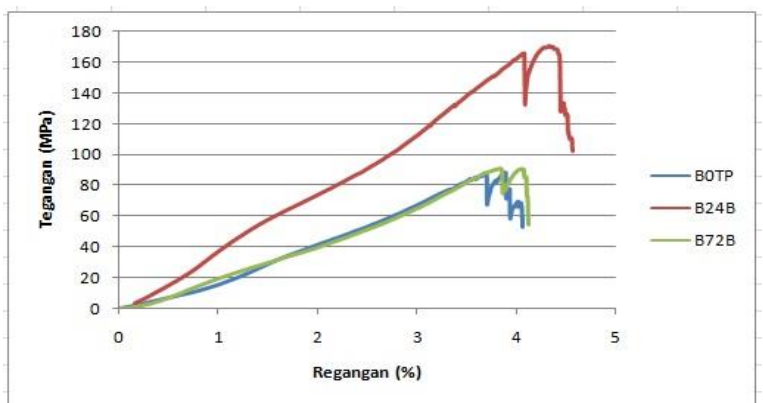

Figure 7. the tensile curve of tension - strain of bamboo betung which is influenced by immersion time on chemical preservation process

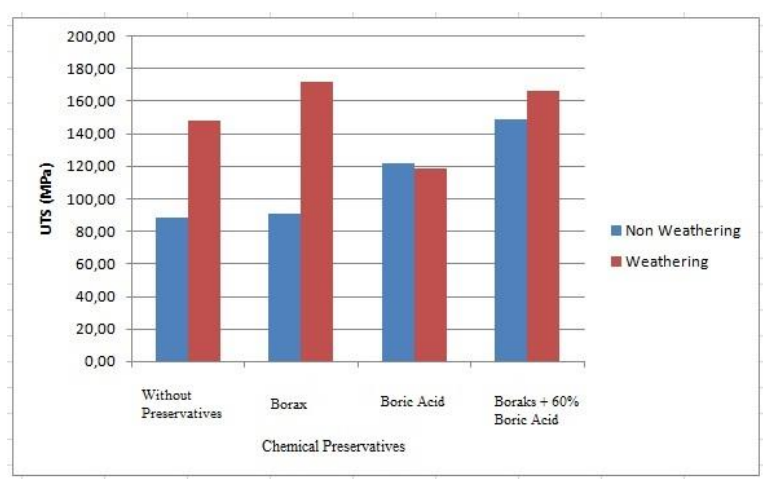

Figure 8 . Graph of tensile strength of bamboo betung non weathering and weathering

TABLE 1.

PROPERTIES OF BORAX $\left(\mathrm{NA}_{2} \mathrm{~B}_{4} \mathrm{O}_{7} .10 \mathrm{H}_{2} \mathrm{O}\right)$

$\begin{array}{cc}\begin{array}{c}\text { Molecular Formula } \\ \text { Physical State }\end{array} & \mathrm{Na}_{2} \mathrm{~B}_{4} \mathrm{O}_{7} \cdot 10 \mathrm{H}_{2} \mathrm{O} \\ \text { Odor } & \text { Odorless } \\ \text { Melting Point } & 741^{\circ} \mathrm{C}\left(1365.8^{\circ} \mathrm{F}\right) \\ \text { Specific Gravity } & 1.71(\text { Water }=1) \\ \% \text { Boron } & 11.34 \% \\ \begin{array}{c}\text { Molecular Weight } \\ \text { Solubility in Water } \\ \left(\% \text { w/w at } 20^{\circ} \mathrm{C}\right)\end{array} & 381.37 \\ \end{array}$

TABLE 2.

PROPERTIES OF BORIC ACID $\left(\mathrm{H}_{3} \mathrm{BO}_{3}\right)$
Molecular Formula

Physical State

Odor

Melting Point

Specific Gravity

$\%$ Boron

Molecular Weight

Solubility in Water

$\left(\% \mathrm{w} / \mathrm{w}\right.$ at $\left.20^{\circ} \mathrm{C}\right)$
$\mathrm{H}_{3} \mathrm{BO}_{3}$ powder

Odorless

$169^{\circ} \mathrm{C}\left(336.2^{\circ} \mathrm{F}\right)$

$1.435($ Water $=1)$

$17.48 \%$

61.83
White or colorless solid crystalline

$4.72 \%$ 
TABLE 3.

ABSORPTION OF CHEMICAL PRESERVATIVES ON BAMBOO BETUNG

\begin{tabular}{|c|c|c|c|c|c|c|}
\hline Sample & $\begin{array}{l}\text { Chemical } \\
\text { pre- } \\
\text { servatives }\end{array}$ & $\begin{array}{c}\text { Immer } \\
\text { sion } \\
\text { time } \\
\text { (hour) }\end{array}$ & $\begin{array}{c}\text { Sampl } \\
\mathrm{e} \\
\text { code }\end{array}$ & $\mathrm{T} 1$ (g) & $\mathrm{T} 2(\mathrm{~g})$ & $\mathrm{G}(\mathrm{g})$ \\
\hline $\begin{array}{l}\text { Bamboo } \\
\text { betung } \\
\text { without } \\
\text { bark }\end{array}$ & $\begin{array}{l}\text { Without } \\
\text { preservativ } \\
\text { es }\end{array}$ & 0 & B0TP & - & - & - \\
\hline $\begin{array}{l}\text { Bamboo } \\
\text { betung } \\
\text { without } \\
\text { bark }\end{array}$ & Borax & 24 & B24B & 23,34 & 25,21 & 1,87 \\
\hline $\begin{array}{l}\text { Bamboo } \\
\text { betung } \\
\text { without } \\
\text { bark }\end{array}$ & Borax & 72 & B72B & 26,33 & 29,78 & 2,28 \\
\hline $\begin{array}{l}\text { Bamboo } \\
\text { betung } \\
\text { with bark }\end{array}$ & Borax & 72 & $\begin{array}{l}\text { BK72 } \\
\text { B }\end{array}$ & 25,52 & 28,22 & 1,26 \\
\hline $\begin{array}{l}\text { Bamboo } \\
\text { betung } \\
\text { without } \\
\text { bark }\end{array}$ & Boric acid & 72 & $\begin{array}{l}\text { B72A } \\
\text { B }\end{array}$ & 25,43 & 28,22 & 2,79 \\
\hline $\begin{array}{l}\text { Bamboo } \\
\text { betung } \\
\text { without } \\
\text { bark }\end{array}$ & $\begin{array}{l}\text { Borax/20\% } \\
\text { Boric acid }\end{array}$ & 72 & $\begin{array}{l}\mathrm{B} 72 \mathrm{~B} \\
120 \% \\
\mathrm{AB}\end{array}$ & 27,13 & 29,54 & 2,41 \\
\hline $\begin{array}{l}\text { Bamboo } \\
\text { betung } \\
\text { without } \\
\text { bark }\end{array}$ & $\begin{array}{l}\text { Borax/40\% } \\
\text { Boric acid }\end{array}$ & 72 & $\begin{array}{l}\mathrm{B} 72 \mathrm{~B} \\
140 \% \\
\mathrm{AB}\end{array}$ & 28,19 & 31,25 & 3,06 \\
\hline $\begin{array}{l}\text { Bamboo } \\
\text { betung } \\
\text { without } \\
\text { bark }\end{array}$ & $\begin{array}{l}\text { Borax/60\% } \\
\text { Boric acid }\end{array}$ & 72 & $\begin{array}{l}\mathrm{B} 72 \mathrm{~B} \\
160 \% \\
\mathrm{AB}\end{array}$ & 28,56 & 30,16 & 1,6 \\
\hline
\end{tabular}

TABLE 4.

ABSORPTION OF CHEMICAL PRESERVATIVES ON BAMBOO BETUNG AFTER WEATHERING

\begin{tabular}{ccccccc} 
Sample & $\begin{array}{c}\text { Chemical } \\
\text { pre- } \\
\text { servatives }\end{array}$ & $\begin{array}{c}\text { Immersion } \\
\text { time } \\
\text { (hour) }\end{array}$ & $\begin{array}{l}\text { Sample } \\
\text { code }\end{array}$ & T1 (g) & T2 (g) & G (g) \\
\hline
\end{tabular}

\begin{tabular}{|c|c|c|c|c|c|}
\hline $\begin{array}{l}\text { Bamboo } \\
\text { betung } \\
\text { without } \\
\text { bark }\end{array}$ & $\begin{array}{l}\text { Without } \\
\text { preservative } \\
\mathrm{s}\end{array}$ & 0 & B0TPW & - & - \\
\hline $\begin{array}{l}\text { Bamboo } \\
\text { betung } \\
\text { without } \\
\text { bark }\end{array}$ & Borax & 72 & B72BW & 28,24 & 31,14 \\
\hline
\end{tabular}

bark

\begin{tabular}{|c|c|c|c|c|c|c|}
\hline $\begin{array}{l}\text { Bamboo } \\
\text { betung } \\
\text { without } \\
\text { bark }\end{array}$ & Boric acid & 72 & $\begin{array}{l}\text { B72AB } \\
W\end{array}$ & 26,77 & 28,96 & 2,19 \\
\hline $\begin{array}{l}\text { Bamboo } \\
\text { betung } \\
\text { without } \\
\text { bark }\end{array}$ & $\begin{array}{l}\text { Borax } / 60 \\
\% \text { Boric } \\
\text { acid }\end{array}$ & 72 & $\begin{array}{l}\mathrm{B} 72 \mathrm{~B} / 60 \\
\% \mathrm{ABW}\end{array}$ & 27,31 & 29,07 & 1,76 \\
\hline
\end{tabular}

TABLE 5 .

RETENTION OF CHEMICAL PRESERVATIVES ON BAMBOO BETUNG

\begin{tabular}{|c|c|c|c|c|c|c|c|}
\hline Sample & $\begin{array}{c}\text { Chemical } \\
\text { preservatives }\end{array}$ & $\begin{array}{l}\text { Immersion } \\
\text { time (hour) }\end{array}$ & $\begin{array}{l}\begin{array}{l}\text { Sample } \\
\text { code }\end{array} \\
\end{array}$ & 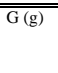 & $\overline{C \mathrm{C}(\%)}$ & $\overline{\mathrm{V}\left(\mathrm{cm}^{3}\right)}$ & $\begin{array}{l}\text { Retention } \\
\text { (gram/cm3) }\end{array}$ \\
\hline Bamboo & $\begin{array}{l}\text { Without } \\
\text { preservatives }\end{array}$ & 0 & В0ТР & - & - & - & - \\
\hline & & 24 & & 1,87 & 1,1 & 30 & 0,7 \\
\hline $\begin{array}{l}\text { Bamboo } \\
\text { betung } \\
\text { without bark }\end{array}$ & Borax & & & & & & \\
\hline $\begin{array}{l}\text { Bamboo } \\
\text { betung } \\
\text { without bark }\end{array}$ & Borax & 72 & B72B & 2,28 & 1,1 & 25 & 1 \\
\hline $\begin{array}{l}\text { Bamboo } \\
\text { betung with } \\
\text { bark }\end{array}$ & Borax & 72 & BK72B & 1,26 & 1,1 & 40 & 0,35 \\
\hline $\begin{array}{l}\text { Bamboo } \\
\text { betung } \\
\text { without bark }\end{array}$ & Boric acid & 72 & $\mathrm{~B} 72 \mathrm{AB}$ & 2,79 & 0,21 & 25 & 0,23 \\
\hline & & 72 & $\begin{array}{l}\mathrm{B} 72 \mathrm{~B} / 20 \% \\
\mathrm{AB}\end{array}$ & 2,41 & 1,31 & 20 & 1,58 \\
\hline $\begin{array}{l}\text { Bamboo } \\
\text { betung } \\
\text { without bark }\end{array}$ & $\begin{array}{l}\text { Borax } / 20 \% \\
\text { Boric acid }\end{array}$ & & & & & & \\
\hline & & 72 & $\begin{array}{l}\mathrm{B} 72 \mathrm{~B} / 40 \% \\
\mathrm{AB}\end{array}$ & 3,06 & 1,31 & 40 & 1 \\
\hline $\begin{array}{l}\text { Bamboo } \\
\text { betung } \\
\text { without bark }\end{array}$ & $\begin{array}{l}\text { Borax } / 40 \% \\
\text { Boric acid }\end{array}$ & & & & & & \\
\hline & & 72 & $\begin{array}{l}\mathrm{B} 72 \mathrm{~B} / 60 \% \\
\mathrm{AB}\end{array}$ & 1,6 & 1,31 & 35 & 0,6 \\
\hline $\begin{array}{l}\text { Bamboo } \\
\text { betung } \\
\text { without bark }\end{array}$ & $\begin{array}{l}\text { Borax } / 60 \% \\
\text { Boric acid }\end{array}$ & & & & & & \\
\hline
\end{tabular}

TABLE 6.

CHEMICAL PRESERVATIVES RETENTION ON BAMBOO BETUNG AFTER WEATHERING

\begin{tabular}{|c|c|c|c|c|c|c|c|}
\hline Sample & $\begin{array}{l}\text { Chemical pre- } \\
\text { servatives }\end{array}$ & $\begin{array}{l}\text { Immersion time } \\
\text { (hour) }\end{array}$ & Sample code & " & 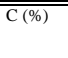 & $\overline{~ V V\left(\mathrm{~cm}^{3}\right)}$ & $\begin{array}{l}\begin{array}{l}\text { Retention } \\
\text { (gram/cm3) }\end{array} \\
\text { (a) }\end{array}$ \\
\hline $\begin{array}{l}\text { Bamboo } \\
\text { betung }\end{array}$ & $\begin{array}{l}\text { Without } \\
\text { preservatives }\end{array}$ & 0 & B0TPW & - & - & - & - \\
\hline $\begin{array}{l}\text { Bamboo } \\
\text { betung } \\
\text { without bark }\end{array}$ & Borax & 72 & $\mathrm{~B} 72 \mathrm{BW}$ & 2,9 & 1,1 & 30 & 1,06 \\
\hline $\begin{array}{l}\text { Bamboo } \\
\text { betung } \\
\text { without bark }\end{array}$ & Boric acid & 72 & $\mathrm{~B} 72 \mathrm{ABW}$ & 2,19 & 0,21 & 20 & 0,23 \\
\hline $\begin{array}{l}\text { Bamboo } \\
\text { betung } \\
\text { without bark }\end{array}$ & $\begin{array}{l}\text { Borax/60\% Boric } \\
\text { acid }\end{array}$ & 72 & $\begin{array}{l}\mathrm{B} 72 \mathrm{~B} / 60 \% \mathrm{~A} \\
\mathrm{BW}\end{array}$ & 1,76 & 1,31 & 35 & 0,66 \\
\hline
\end{tabular}


TABEL 7.

THE EFFECT OF CHEMICAL PRESERVATIVES AND IMMERSION TIME TO TENSILE STRENGTH OF BAMBOO BETUNG

\begin{tabular}{|c|c|c|c|c|}
\hline Sample & $\begin{array}{c}\text { Chemical } \\
\text { preservatives }\end{array}$ & $\begin{array}{l}\text { Immersion } \\
\text { time (hour) }\end{array}$ & Sample code & $\begin{array}{l}\text { UTS } \\
(\mathrm{MPa})\end{array}$ \\
\hline $\begin{array}{l}\text { Bamboo betung } \\
\text { without bark }\end{array}$ & $\begin{array}{l}\text { Without } \\
\text { preservatives }\end{array}$ & 0 & B0TP & 88,52 \\
\hline $\begin{array}{l}\text { Bamboo betung } \\
\text { without bark }\end{array}$ & Borax & 24 & B24B & 170,59 \\
\hline $\begin{array}{l}\text { Bamboo betung } \\
\text { without bark }\end{array}$ & Borax & 72 & B72B & 90,62 \\
\hline $\begin{array}{l}\text { Bamboo betung } \\
\text { with bark }\end{array}$ & Borax & 72 & BK72B & 132,18 \\
\hline $\begin{array}{l}\text { Bamboo betung } \\
\text { without bark }\end{array}$ & Boric acid & 72 & $\mathrm{~B} 72 \mathrm{AB}$ & 122,1 \\
\hline $\begin{array}{l}\text { Bamboo betung } \\
\text { without bark }\end{array}$ & $\begin{array}{l}\text { Borax } / 20 \% \\
\text { Boric acid }\end{array}$ & 72 & $\mathrm{~B} 72 \mathrm{~B} / 20 \% \mathrm{AB}$ & 83,75 \\
\hline $\begin{array}{l}\text { Bamboo betung } \\
\text { without bark }\end{array}$ & $\begin{array}{l}\text { Borax } / 40 \% \\
\text { Boric acid }\end{array}$ & 72 & $\mathrm{~B} 72 \mathrm{~B} / 40 \% \mathrm{AB}$ & 94,17 \\
\hline $\begin{array}{l}\text { Bamboo betung } \\
\text { without bark }\end{array}$ & $\begin{array}{l}\text { Borax } / 60 \% \\
\text { Boric acid }\end{array}$ & 72 & $\mathrm{~B} 72 \mathrm{~B} / 60 \% \mathrm{AB}$ & 149,37 \\
\hline
\end{tabular}

TABLE 8.

THE EFFECT OF CHEMICAL PRESERVATIVES TO TENSILE STRENGTH OF BAMBOO BETUNG

\begin{tabular}{|c|c|c|c|c|}
\hline Sample & $\begin{array}{c}\text { Chemical } \\
\text { preservatives }\end{array}$ & $\begin{array}{l}\text { Immersion } \\
\text { time (hour) }\end{array}$ & Sample code & $\begin{array}{l}\text { UTS } \\
\text { (MPa) }\end{array}$ \\
\hline $\begin{array}{l}\text { Bamboo betung } \\
\text { without bark }\end{array}$ & $\begin{array}{l}\text { Without } \\
\text { preservatives }\end{array}$ & 0 & В0TP & 88,52 \\
\hline $\begin{array}{l}\text { Bamboo betung } \\
\text { without bark }\end{array}$ & Borax & 72 & B72B & 90,62 \\
\hline $\begin{array}{l}\text { Bamboo betung } \\
\text { without bark }\end{array}$ & Boric acid & 72 & $\mathrm{~B} 72 \mathrm{AB}$ & 122,1 \\
\hline $\begin{array}{l}\text { Bamboo betung } \\
\text { without bark }\end{array}$ & $\begin{array}{l}\text { Borax } / 20 \% \\
\text { Boric acid }\end{array}$ & 72 & $\mathrm{~B} 72 \mathrm{~B} / 20 \% \mathrm{AB}$ & 83,75 \\
\hline $\begin{array}{l}\text { Bamboo betung } \\
\text { without bark }\end{array}$ & $\begin{array}{l}\text { Borax } / 40 \% \\
\text { Boric acid }\end{array}$ & 72 & $\mathrm{~B} 72 \mathrm{~B} / 40 \% \mathrm{AB}$ & 94,17 \\
\hline $\begin{array}{l}\text { Bamboo betung } \\
\text { without bark }\end{array}$ & $\begin{array}{l}\text { Borax } / 60 \% \\
\text { Boric acid }\end{array}$ & 72 & $\mathrm{~B} 72 \mathrm{~B} / 60 \% \mathrm{AB}$ & 149,37 \\
\hline
\end{tabular}

TABLE 9.

THE BARK EFFECT TO TENSILE STRENGTH OF BAMBOO BETUNG ON CHEMICAL PRESERVATION PROCESS

\begin{tabular}{llccc}
\hline \hline Sample & $\begin{array}{c}\text { Chemical } \\
\text { preservatives }\end{array}$ & $\begin{array}{c}\text { Immersion } \\
\text { time (hour) }\end{array}$ & $\begin{array}{c}\text { Sample } \\
\text { code }\end{array}$ & $\begin{array}{l}\text { UTS } \\
\text { (MPa) }\end{array}$ \\
\hline $\begin{array}{l}\text { Bamboo } \\
\text { betung } \\
\text { without bark }\end{array}$ & $\begin{array}{l}\text { Without } \\
\text { preservatives }\end{array}$ & 0 & B0TP & 88,52 \\
$\begin{array}{l}\text { Bamboo } \\
\text { betung }\end{array}$ & Borax & 72 & B72B & 90,62 \\
$\begin{array}{l}\text { without bark } \\
\text { Bamboo } \\
\text { betung with } \\
\text { bark }\end{array}$ & Borax & 72 & BK72B & 132,18 \\
\hline \hline
\end{tabular}

TABLE 10 .

THE EFFECT OF IMMERSION TIME TO TENSILE STRENGTH OF BAMBOO BETUNG

\begin{tabular}{llccc}
\hline \hline \multicolumn{1}{c}{ Sample } & $\begin{array}{c}\text { Chemical } \\
\text { preservatives }\end{array}$ & $\begin{array}{c}\text { Immersion time } \\
\text { (hour) }\end{array}$ & $\begin{array}{c}\text { Sample } \\
\text { code }\end{array}$ & $\begin{array}{l}\text { UTS } \\
\text { (MPa) }\end{array}$ \\
\hline $\begin{array}{l}\text { Bamboo betung } \\
\text { without bark }\end{array}$ & $\begin{array}{l}\text { Without } \\
\text { preservatives }\end{array}$ & 0 & B0TP & 88,52 \\
$\begin{array}{l}\text { Bamboo betung } \\
\text { without bark }\end{array}$ & Borax & 24 & B24B & 170,59 \\
$\begin{array}{l}\text { Bamboo betung } \\
\text { without bark }\end{array}$ & Borax & 72 & B72B & 90,62 \\
\hline \hline
\end{tabular}

TABLE 11.

THE TENSILE STRENGTH OF BAMBOO BETUNG NON WEATHERING AND WEATHERING

\begin{tabular}{lllcc}
\hline & Chemical & Immersi Sample & Non & Sample code Weathering \\
Sample & Pre- & on Time code & Weatheri & (UTS) \\
& servatives & (hour) & ng (UTS) &
\end{tabular}

\begin{tabular}{|c|c|c|c|c|c|c|}
\hline $\begin{array}{l}\text { Bamboo } \\
\text { betung } \\
\text { without bark }\end{array}$ & $\begin{array}{l}\text { Without } \\
\text { preservatives }\end{array}$ & 0 & B0TP & 88,52 & B0TPW & 148,16 \\
\hline $\begin{array}{l}\text { Bamboo } \\
\text { betung } \\
\text { without bark }\end{array}$ & Borax & 72 & B72B & 90,62 & B72BW & 172,21 \\
\hline $\begin{array}{l}\text { Bamboo } \\
\text { betung } \\
\text { without bark }\end{array}$ & Boric acid & 72 & $\mathrm{~B} 72 \mathrm{AB}$ & 122,10 & $\mathrm{~B} 72 \mathrm{ABW}$ & 118,80 \\
\hline $\begin{array}{l}\text { Bamboo } \\
\text { betung } \\
\text { without bark }\end{array}$ & $\begin{array}{l}\text { Borax } / 60 \% \\
\text { boric acid }\end{array}$ & 72 & $\begin{array}{c}\mathrm{B} 72 \mathrm{~B} / 6 \\
0 \% \mathrm{AB}\end{array}$ & 149,37 & $\begin{array}{c}\mathrm{B} 72 \mathrm{~B} / 60 \% \mathrm{~A} \\
\mathrm{~B}\end{array}$ & 166,61 \\
\hline
\end{tabular}

